\title{
Studi Kasus
}

\section{Penurunan kecemasan pada pasien gagal jantung kongestif melalui pemberian terapi murottal Al-Qur'an}

\author{
Meliawati Putri Salsabila1, Heryanto Adi Nugroho' ${ }^{1}$ \\ 1 Program Studi Pendidikan Profesi Ners, Fakultas Ilmu Keperawatan dan Kesehatan, Universitas \\ Muhammadiyah Semarang
}

\section{Informasi Artikel}

\begin{tabular}{lll}
\hline \multicolumn{3}{l}{ Riwayat Artikel: } \\
- Submit $\quad 16$ & September \\
& 2020 \\
- Diterima & & \\
& 30 & Desember \\
- Diterbitkan & 31 & Desember \\
& 2021 \\
& &
\end{tabular}

Kata kunci:

Gagal jantung Kongestif; Kecemasan; Terapi Murottal

\begin{abstract}
Abstrak
Gagal jantung meningkatkan resiko kematian mendadak sehingga membutuhkan penanganan sesuai dengan tingkat keparahannya. Pada pasien penyakit kardiovaskuler lazim merasakan kecemasan dan stress. Kecemasan pada pasien dengan penyakit kardiovaskuler dapat dibantu salah satunya dengan tindakan non farmakologi. Pada studi kasus ini penanganan kecemasan pasien gagal jantung menggunakan intervensi terapi murottal al-qur'an. Tujuan umum studi kasus ini untuk menganalisa penurunan tingkat kecemasan pasien gagal jantung terhadap pemberian terapi murottal al-qur'an. Studi kasus ini menggunakan metode deskriptif dengan pendekatan proses keperawatan. Subjek studi kasus ini adalah pasien gagal jantung kongestif dan berjumlah 2 orang yang didapatkan secara purposive sampling. Studi kasus ini dilakukan di Ruang Ayyub 2 RS. Roemani Kota Semarang pada tanggal 13 Februari 2020 - 15 Februari 2020. Pengkajian kecemasan dan pengukuran tingkat kecemasan menggunakan kuisioner HARS (Hamilton Rating Scale Of Anxiety). Prosedur pelaksanaan studi kasus ini dilakukan sesuai dengan evidence based nursing yaitu dilaksanakan dengan durasi 15-20 menit selama 3 hari. Hasil studi evaluasi menunjukkan bahwa sebelum dilakukan terapi murottal al-qur'an terjadi peningkatan kecemasan dan tanda-tanda vital serta gangguan tidur pada kedua pasien yang mengalami penurunan setelah dilakukan terapi murottal al-qur'an.Setelah dilakukan terapi murottal al-qur'an terdapat perbaikan pada tanda-tanda vital, penurunan tingkat kecemasan, dan penurunan gangguan tidur pada kedua pasien. Terapi murottal al-qur'an efektif dalam menurunkan tingkat kecemasan pada pasien dengan gagal jantung kongestif.
\end{abstract}

\section{PENDAHULUAN}

Penyakit gagal jantung menjadi salah satu perhatian di bidang kesehatan. Tingginya angka kejadian di berbagai negara membuat penyakit gagal jantung menjadi salah satu target utama yang harus diselesaikan. Saat ini penyakit gagal jantung telah dinobatkan sebagai penyebab kematian nomor satu di dunia. Angka kejadian gagal jantung di dunia lebih dari 20 juta orang pertahunnya (WHO, 2016). Di Indonesia sendiri angka kejadian penyakit gagal jantung terbilang tinggi. Prevalensi berdasarkan Riskesdas prevalensi tertinggi berada di NTT sebesar 0,8\%, dan terendah berada di Kalimantan Timur, Bangka Belitung, Lampung, dan Jambi sebesar 0,1\% (Riskesdas, 2018).

Pasien gagal jantung akan mengalami komplikasi diantara lain syok kardiogenik,

Corresponding author:

Meliawati Putri Salsabila

salsabila1386@gmail.com

Ners Muda, Vol 2 No 3, Desember 2021

e-ISSN: 2723-8067

DOI: https://doi.org/10.26714/nm.v2i3.6283 
Meliawati Putri Salsabila - Penurunan kecemasan pada pasien gagal jantung kongestif melalui pemberian terapi murottal Al-Qur'an

efusi pericardial dan tamponade jantung serta kematian (Smeltzer \& B.G. Bare, 2015). Komplikasi terakhir dari gagal jantung adalah kematian. Gagal jantung meningkatkan resiko kematian mendadak sehingga membutuhkan penanganan sesuai dengan tingkat keparahannya. (M.F. Douglas L., 2010). Angka kematian akibat gagal jantung di Indonesia terbilang tinggi, yakni mencapai $25 \%$ pada 1 tahun dan $50 \%$ pada 5 tahun pertama pasca diagnosis. Angka kematian pada pasien dengan gagal jantung yang di rawat di rumah sakit mencapai 6,7\%, angka tersebut lebih tinggi dari estimasi angka kematian pasien gagal jantung yang di rawat di rumah sakit di kawasan Asia Pasifik (Pusat Jantung Nasional, 2016).

Pasien gagal jantung akan mengalami perubahan fisik dan psikologis, perubahan fisik yang muncul seperti penurunan curah jantung yang ditunjukkan dengan oliguria, takikardi dan palpitasi, pucat, nadi perifer melemah. Kongesti pulmonal memberikan perubahan fisik berupa dyspnea, krakels, dan takipnea. Perubahan fisik lainnya berupa edema menetap, distensi vena jugularis, dan distensi abdomen (Davey, 2014). Masalah psikologis yang muncul pada pasien gagal jantung antara lain stress, kecemasan, ketidakberdayaan, ketakutan dan depresi (Polikandrioti et al., 2015). Penyakit gagal jantung sangat berdampak pada kualitas hidup pasien.

Pada pasien dengan terdiagnosa penyakit tahunan seperti penyakit gagal jantung lazim merasakan kecemasan dan stress. Pasien-pasien dengan gagal jantung mengekspresikan ketakutan dengan berbagai cara seperti cemas yang berlebihan, mimpi buruk, gelisah, insomnia, dan menyangkal kenyataan yang ada (Ketut et al., 2014). Pasien gagal jantung memiliki beragam penerimaan terhadap kondisinya, tidak semua memiliki penerimaan seperti yang diharapkan beberapa bahkan menunjukan mekanisme koping maladaptif seperti penolakan ekstrim, agresif dan percobaan bunuh diri (Ladwig et al., 2014). Pada penelitian sebelumnya mengatakan bahwa hasil dari peningkatan pemantauan diri pasien gagal jantung mengatakan keadaan emosionalnya semakin buruk dan keyakinan bahwa penyakit yang dialami berada diluar kendali. Individu gagal memahami kondisinya sehingga individu akan memikirkan hal-hal yang kemungkinan akan terjadi pada dirinya, hal tersebut akan menimbulkan masalah psikologis pada individu (Godman et al., 2013).

Apabila meknisme koping pasien gagal jantung dalam menghadapi perubahan yang diterima semakin adaptif, maka tingkat masalah psikologisnya akan semakin rendah. Namun, apabila mekanisme koping dalam menerima perubahan yang muncul adalah maladaptive, maka gejala akan berpengaruh pada lebih beratnya gejala fisik dan gejal psikologis yang muncul sehingga proses rehabilitasinya semakin lama. Dampak dari kecemasan ini dapat mengakibatkan hemodinamika pasien gagal jantung terganggu (Brunner\&Suddart, 2014).

Salah satu intervensi keperawatan yang dapat diberikan untuk mengatasi kecemasan pada pasien gagal jantung adalah terapi murottal al-qur'an.

Pada studi kasus ini penanganan kecemasan pasien gagal jantung menggunakan terapi murottal al-qur'an berdasarkan pada jurnal penelitian sebelumnya (Saleh et al., 2018). Penelitian tersebut diterapkan pada 15 pasien yang di melalui teknik purposive sampling dan dilaksanakan selama 3 hari. Pada penelitian tersebut didapatkan hasil bahwa terdapat penurunan tingkat kecemasan pada pasien gagal jantung setelah dberikan intervensi murottal alqur'an yang semula berada pada tingkat sedang turun menjadi tingkat ringan. Hasil penelitian menyebutkan bahwa terapi 
Meliawati Putri Salsabila - Penurunan kecemasan pada pasien gagal jantung kongestif melalui pemberian terapi murottal Al-Qur'an

murottal al-qur'an berpengaruh terhadap tingkat kecemasan pasien jantung (Saleh et al., 2018).

Berbagai hasil penelitian lain mengungkapkan terapi murotal al-quran sangat efektif dalam menurunkan kecemasan pasien karena stimulan alqur'an rata-rata didominasi oleh gelombang delta, dimana gelombang ini mengakibatkan kondisi otak berada dalam keadaan yang sangat relaks sehingga stimulan al-qur'an dapat memberikan ketenangan, ketentraman, dan kenyamanan (Lestari, 2015). Menurut penelitian sebelumnya menyebutkan bahwa terdapat penurunan pada tingkat kecemasan pasien setelah pemberian terapi murottal. Murottal al-qur'an memiliki ritme yang konstan, teratur dan tidak ada perubahan yang drastis sehingga menstimulasi pelepasan endorphine pada sistem pengaturan dan memberikan dampak relaksasi serta dapat menurunkan stress dan kecemasan (Darmadi \& Armiyati, 2019).

Tujuan umum studi kasus ini untuk menganalisa penurunan tingkat kecemasan pasien gagal jantung terhadap pemberian terapi murottal al-qur'an. Tujuan khusus studi kasus ini yaitu penulis mampu melakukan pengkajian kecemasan pada pasien dengan penyakit jantung, merumuskan masalah diagnosa keperawatan kecemasan pada pasien dengan penyakit jantung, menyusun rencana asuhan keperawatan kecemasan pada pasien dengan penyakit jantung, melakukan implementasi pada pasien dengan penyakit jantung, melakukan evaluasi pada pasien dengan penyakit jantung.

\section{METODE}

Metode yang digunakan dalam studi kasus ini adalah deskriptif dengan pendekatan proses asuhan keperawatan. Metode deskriptif yaitu menggambarkan mengenai proses asuhan keperawtan dengan memfokuskan pada salah satu masalah penting dalam asuhan keperawatan pada pasien gagal jantung. Subjek dari studi kasus ini adalah pasien dengan gagal jantung kronis sebanyak 2 orang yang dipilih dengan kriteria inklusi dan eksklusi sesuai dengan jurnal Evidence Based Nursing. Kriteria inklusi pada studi kasus ini yaitu pasien yang baru didiagnosa penyakit jantung, pasien yang beragama islam, pasien pria dan wanita, pasien pasien dalam keadaan sadar dan bersedia menjadi responden studi kasus.

Studi kasus ini dilakukan di Ruang Ayyub 2 RS. Roemani Kota Semarang pada tanggal 13 Februari 2020 - 15 Februari 2020. Proses keperawatan yang dilakukan untuk mendapatkan data dengan cara pengkajian, penegakan diagnosa keperawatan, Intervensi, implementasi (tindakan keperawatan), dan evaluasi. Proses pelaksanaan studi kasus ini dilakukan sesuai dengan penelitian sebelumnya yaitu dilaksanakan dengan durasi 15-20 menit selama 3 hari. Sebelum dilakukan terapi murotal Al-qur'an dilakukan pengkajian kecemasan dan pengukuran tingkat kecemasan terlebih dahulu menggunakan kuisioner HARS (Hamilton Rating Scale of Anxiety), kemudian setelah dilakukan terapi murottal dilakukan pengkajian kecemasan dan pengukuran tingkat kecemasan kembali.

Tahapan studi kasus ini diawali dengan memperkenalkan diri dan menjelaskan tujuan serta prosedur pelaksanaan dan meminta persetujuan pasien, kemudian dilakukan pengukuran kecemasan sebelum dilakukan tindakan, melakukan pemasangan earphone yang terhubung dengan handphone dan menyalakan murottal al-qur'an dengan surah Ar-rahman yang dilantunkan oleh muzammil hasbullah selama 15 menit,kemudian dilakukan pengukuran tingkat kecemasan kembali 
Meliawati Putri Salsabila - Penurunan kecemasan pada pasien gagal jantung kongestif melalui pemberian terapi murottal Al-Qur'an

setelah dilakukan intervensi. Intervensi ini dilakukan selama 3 hari.

\section{HASIL}

Subjek studi kasus ini berjumlah 2 orang yang terdiri dari pasien laki-laki dan perempuan. Pasien pertama dilakukan pengkajian pada tanggal 13 Februari 2020. Pasien 1 (64 tahun) didiagnosa gagal jantung pada tanggal 13 Februari 2020, pasien mengatakan sesak nafas, nyeri dada kiri, nyeri dada bertambah saat beraktivitas, khawatir dengan kondisinya, tidak bisa tidur, mengungkapkan ketidakberdayaannya, memiliki firasat buruk pada dirinya. Pasien menunjukkan raut wajah cemas dan selama dilakukan pengkajian pasien menjawab dengan singkat. Tanda tanda vital yang didapatkan yaitu tekanan darah 176/70, Frekuensi Nadi $12 \mathrm{x} / \mathrm{mnt}$, frekuensi Pernapasan 29x/mnt, CRT: 3 detik, dan nadi teraba lemah, terpasang oksigen nasal kanul 6 1/menit. Hasil pengukuran skala kecemasan menggunakan HARS didapatkan poin 41 dengan interpretasi kecemasan berat. Dari hasil pengkajian didapatkan diagnose keperawatan yaitu ansietas berhubungan dengan ancaman terhadap kematian.

Pasien kedua dilakukan pengkajian pada tanggal 13 februari 2020. Pasien 2 (46 tahun ) didiagnosa gagal jantung kongestif pada tanggal 11 Februari 2020. Pasien mengatakan sesak napas, nyeri pada dada kiri, dan mengeluh cemas dengan kondisinya saat ini, setiap kali mengingat penyakitnya Pasien merasa berdebar dan kemudian sulit untuk tidur serta sering mimpi buruk. Tampak edema pada kaki pasien, selama dilakukan pengkajian pasien menjawab dengan singkat dan raut wajah yang gelisah dengan suara yang pelan. Tanda-tanda vital yang didapatkan yaitu Tekanan darah 159/80, Nadi: 98x/mnt, frekuensi pernapasan $27 \mathrm{x} / \mathrm{mnt}$, CRT 3 detik, frekuensi nadi $98 \mathrm{x} /$ menit, Nadi teraba lemah, terpasang oksigen nasal kanul 4 liter/menit. Hasil pengukuran skala kecemasan menggunakan HARS didapatkan poin 43 dengan interpretasi kecemasan berat. Dari hasil pengkajian didapatkan diagnosa keperawatan yaitu ansietas berhubungan dengan ancaman terhadap kematian.

Data hasil pengkajian tersebut menunjukkan kedua pasien mengalami peningkatan tekanan darah. Hipertensi menyebabkan kerusakan serius pada jantung, tekanan yang berlebih membuat pembuluh darah menjadi sclerosis serta aliran darah dan oksigen ke jantung berkurang. Hal ini berakibat pada jantung tidak dapat memompa cukup darah dan oksigen ke organ tubuh vital lainnya (Donsu et al., 2020). Kecemasan yang dialami pasien akan berdampak pula pada tekanan darah pasien seperti yang disebutkan pada penelitian sebelumnya yang menyebutkan bahwa stimulus syaraf simpatik yang disebabkan oleh kecemasan akan mengakibatkan peningkatan tekanan darah yang sebabkan karena peningkatan frekuensi denyut jantung dan peningkatan tekanan pembuluh perifer (Paul M. Muchinsky, 2018).

Kedua pasien mengalami nyeri dada dan sesak nafas dan terpasang oksigen nasal kanul, kondisi inilah yang memicu ketakutan dan kekhawatiran yang diungkapkan oleh kedua pasien. Penelitian sebelumnya yang mengatakan bahwa kecemasan yang terjadi pada kebanyakan pasien gagal jantung dikarenakan mereka mengalami kesulitan mempertahankan oksigenasi yang adekuat sehingga mereka cenderung sesak nafas dan gelisah (Suratinoyo et al., 2016). Kecemasan dan takut juga akan berdampak pada meningkatnya frekuensi dan kedalaman dengan perubahan irama sebagai sebagai akibat dari stimulasi simpatik (Donsu et al., 2020). 
Meliawati Putri Salsabila - Penurunan kecemasan pada pasien gagal jantung kongestif melalui pemberian terapi murottal Al-Qur'an

Diagnosis utama dalam studi kasus ini adalah ansietas (D.0080) berhubungan dengan ancaman terhadap kematian (PPNI, 2017). Data mayor subjek studi kasus menunjukkan adanya rasa kekhawatiran dengan akibat dari kondisi yang dihadapi, sulit tidur, raut muka tegang. Hal ini ditunjukkan pada subjek mengeluh takut, cemas, dan khawatir pada kondisinya saat ini, mengungkapkan adanya firasat buruk pada diri sendiri dan juga adanya mimpi buruk, mengatakan sulit tidur dan raut wajah yang tegang. Ansietas diambil penulis menjadi diagnosis keperawatan utama dengan mempertimbangkan kondisi klinin subjek studi kasus. Subjek studi kasus mengalami peningkatan hemodinamika dan nyeri dada yang mengakibatkan kecemasan, kecemasan yang muncul akan semakin mengganggu kondisi hemodinamika pasien sehingga proses rehabilitasinya semakin lama.

Luaran utama dari diagnosa ansietas adalah Tingkat ansietas menurun (L.09093) dengan kriteria hasil verbalisasi kekhawatiran akibat kondisi yang dihadapi menurun, perilaku tegang menurun, frekuensi pernapasan menurun, frekuensi nadi menurun, frekuensi tekanan darah menurun, dan pola tidur membaik (PPNI, 2017). Intervensi keperawatan subjek pada studi kasus ini yaitu Reduksi Ansietas (1.09314). reduksi ansietas yang direncanakan antara lain observasi (monitor tanda-tanda vital), terapeutik (ciptakan suasana terapeutik untuk menumbuhkan kepercayaan, gunakan pendekatan yang tenang dan meyakinkan), Edukasi ( anjurkan keluarga untuk tetap bersama pasien). Intervensi lain yaitu terapi relaksasi (1.09326). terapi relaksasi yang direncanakan antara lain observasi (identifikasi penurunan tingkat energi, ketidakmampuan berkonsentrasi, atau gejala lain yang mengganggu kemampuan kognitif, periksa ketegangan otot, frekuensi nadi, tekanan darah sebelum dan sesudah latihan), terapeutik (gunakan relaksasi sebagai strategi penunjang), edukasi (anjurkan mengambil posisi nyaman) (PPNI, 2017) . salah satu intevensi yang dapat diterapkan adalah terapi murottal alqur'an.

Implementasi keperawatan yang dilakukan untuk menurunkan kecemasan pada studi kasus ini antara lain yang pertama adalah identifikasi penurunan tingkat energi, ketidakmampuan berkonsentrasi, atau gejala yang mengganggu kemampuan kognitif serta memonitor tanda tanda vital, kemudian menjalin kepercayaan kepada pasien dengan menciptakan kenyamanan saat berkunjung atau berkomunikasi dengan pasien, dan menganjurkan pasien berada pada posisi yang nyaman dan menganjurkan keluarga untuk menemani pasien. Setelah mengamati perkembangan kecemasan pasien dan didapatkan belum adanya perubahan yang berarti, maka dilakukanlah tindakan terapi tambahan dengan murottal alqur'an. Pada studi kasus ini menerapkan implementasi murottal alqur'an surah Ar-Rahman yang dilakukan 1 hari sekali selama 3 hari asuhan keperawatan, setiap sesi dilakukan selama 15 menit. Implementasi ini dilakukan berdasarkan penelitian sebelumnya yang dilakukan oleh (Saleh et al., 2018).

Pada proses pelaksanaan terapi mendapat dukungan dari keluarga pasien yang sangat terbuka. Keluarga pasien membantu memberikan dukungan dan kenyamanan pada pasien selama berjalannya terapi. Respon pasien setelah diberikan terapi murottal al-qur'an surah Ar-Rahman pada hari pertama mengatakan merasa lebih rileks, namun masih merasa khawatir dan takut, tanda tanda vital mengalami penurunan serta poin tingkat kecemasan mengalami penurunan. Pertemuan kedua dan ketiga sebelum dilakukan terapi murottal al-qur'an mengeluhkan masih merasa khawatir dengan kondisinya dan mengungkapkan ketidakberdayaan, dan terdapat peningkatan tanda-tanda vital, 
Meliawati Putri Salsabila - Penurunan kecemasan pada pasien gagal jantung kongestif melalui pemberian terapi murottal Al-Qur'an

setelah dilakukan terapi murottal al-qur'an surah Ar-Rahman pasien mengungkapkan respon rileks dan nyaman, menyampaikan sudah bisa tidur dan tanda-tanda vital menurun.

Hasil studi kasus tingkat kecemasan pasien hari pertama saat pengkajian pada pasien 1 yaitu pasien mengungkapkan perasaan tenang dan kekhawatiran sedikit berkurang, terdapat penurunan tanda tanda vital yaitu frekuensi nadi menjadi $95 \mathrm{x} /$ menit, frekuensi napas menjadi 25x/menit, tekanan darah 160/72 mmHg, dan poin total tingkat kecemasan yang diukur menggunakan HARS turun menjadi 39. Pada pasien 2 menunjukkan hasil yaitu pasien mengungkapkan perasaan nyaman dan tenang, mengatakan masih merasa berdebar dan merasa takut namun sudah mulai mencoba untuk ikhlas dengan kondisinya, terdapat penurunan tanda tanda vital yaitu frekuensi nadi menjadi 95x/menit, frekuensi napas menjadi 26x/menit, dan tekanan darah menjadi $150 / 70 \mathrm{mmHg}$, poin total tingkat kecemasan yang diukur menggunakan HARS turun menjadi 41.. Pada pertemuan kedua pasien 1 menunjukkan hasil yaitu klien mengatakan merasa lebih tenang dan nyaman, sudah mulai bisa tidur namun terkadang masih merasa khawatir, tandatanda vital menunjukkan hasil yaitu frekuensi nadi 95x/menit, frekuensi napas 25x/menit, tekanan darah 160/72 mmHg, dan poin tingkat kecemasan turun menjadi 36. Pada pasien 2 menunjukkan hasil yaitu pasien mengungkapkan perasaan nyaman dan tenang, dapat tidur dan istirahat dengan lebih tenang, saat teringat dengan penyakitnya masih merasa berdebar namun mencoba untuk ikhlas dengan kondisinya, tanda-tanda vital menunjukkan hasil yaitu frekuensi nadi turun menjadi $80 \mathrm{x} /$ menit, frekuensi napas turun menjadi $22 \mathrm{x} /$ menit, tekanan darah menjadi $147 / 70 \mathrm{mmHg}$, dan poin tingkat kecemasan turun menjadi 37. Pada pertemuan ketiga menunjukkan hasil yaitu pada pasien 1 mengungkapkan perasaan tenang dan nyaman, masih merasa takut dan tidak berdaya karena kondisinya, raut wajah rileks, tanda-tanda vital menunjukkan penurunan yaitu frekuensi nadi menjadi 98x/menit, frekuensi napas menjadi $25 \mathrm{x} /$ menit, tekanan darah menjadi 157/70 mmHg, dan poin tingkat kecemasan pasien menjadi 32 . Pada pasien 2 menunjukkan hasil yaitu pasien mengungkapkan perasaan tenang dan juga sudah bisa tidur, tanda-tanda vital menunjukkan terdapat penurunan yaitu pada frekuensi nadi menjadi $80 \mathrm{x} /$ menit, frekuensi napas menjadi $22 \mathrm{x} /$ menit, tekanan darah menjadi 146/75 $\mathrm{mmHg}$, dan poin tingkat kecemasan turun menjadi 34 .

Terapi murotal al-quran sangat efektif dalam menurunkan kecemasan pasien karena stimulan al-qur'an rata-rata didominasi oleh gelombang delta, dimana gelombang ini mengindikasikan bahwa kondisi otak sebenarnya berada dalam keadaan yang sangat relaks sehingga stimulan al-qur'an dapat memberikan ketenangan, ketentraman, dan kenyamanan (Lestari, 2015). mirottal Al-qur'an menstimulasi pelepasan endorphine dan memberi efek relaksasi dan dapat menurunkan stress dan kecemasan (Darmadi \& Armiyati, 2019).

Kedua pasien pada dasarnya kooperatif, namun dalam berkomunikasi hanya menjawab dengan singkat sehingga penulis perlu menggali lebih dalam untuk mendapatkan poin pertanyaan dan jawaban yang dimaksudkan. Raut wajah pasien menampakkan kecemasan terlebih ketika menyampaikan kekhawatiran terkait kondisinya, pasien menyampaikan secara verbal terkait keadaan istirahat yang terganggu dan susah tidur akibat sesak napas dan ditambah dengan rasa cemas dan tidak tenang, perasaan tentang firasat buruk atas keadaannya dan bahkan pasien 2 mengalami mimpi buruk. Pasien 2 cenderung mengalami kecemasan lebih dibanding dengan pasien 1 meskipun 
Meliawati Putri Salsabila - Penurunan kecemasan pada pasien gagal jantung kongestif melalui pemberian terapi murottal Al-Qur'an

memiliki firasat buruk, pasien 1 tetap berusaha pasrah kepada Allah S.W.T. Keluarga pasien 1 dan 2 antusias dan terbuka, serta sangat kooperatif. Keluarga kedua pasien membantu memberikan dukungan dan membantu menenangkan pasien.

\section{PEMBAHASAN}

Pasien studi kasus ini berusia 64 tahun dan 45 tahun, pada penelitian sebelumnya menjelaskan bahwa kelompok usia yang menderita gagal jantung yaitu 40-49 tahun sebanyak 17 pasien $(19,1 \%), 50-59$ tahun sebanyak 20 pasien $(22,5 \%)$ dan $>60$ tahun sebanyak 49 pasien (55\%), dan kelompok usia terbanyak adalah usia $>60$ tahun (Donsu et al., 2020). Dengan bertambahnya usia, terjadi penurunan baik dalam jumlah maupun fungsi miosit jantung, peningkatan nekrosis dan apoptosis misot, serta penurunan kapasitas regeneratif sel-sel progenitor jantung. Keadaan ini mempengaruhi seluruh sistem pembuluh darah dan menyebabkan fibrosis dinding pembuluh darah arteri serta penebalan dan pengerasan dinding pembuluh darah sehingga semakin menambah tekanan pada jantung dan memperburuk hipertrofi yang berujung pada berkembangnya penyakit jantung. Usia pasien juga akan berpengaruh pada kualitas hidup pasien seperti yang dikatakan pada penelitian lain bahwa pada lansia berumur 40 tahun keatas yang tidak aktif jantung kirinya mengalami pengecilan sebagai respon terhadap rendahnya beban kerja yang dibutuhkan dan umur merupakan faktor yang mempengaruhi kualitas hidup pasien (Akhmad, 2018).

Pasien studi kasus ini didapatkan 2 orang dengan jenis kelamin laki-laki dan perempuan. Pada penelitian (Suratinoyo et al., 2016) dijelaskan bahwa jenis kelamin yang paling banyak menderita gagal jantung adalah jenis kelamin laki-laki dengan hasil penelitian pasien gagal jantung berjenis kelamin laki-laki sebanya 19 orang $(57,6 \%)$ dan perempuan sebanyak 14 orang $(42,4 \%)$. Faktor resiko gagal jantung kongestif pada perempuan cenderung lebih rendah disbanding laki-laki karena perempuan memiliki hormon estrogen yang dapat menghasilkan high density lipoprotein (HDL), pada kondisi menurun atau hilangnya kadar estrogen pada perempuan pada saat menopause mengakibatkan meningkatnya kadar trigliserida dan penurunan lemak total, sehingga akan meningkatkan resiko terkena penyakit gagal jantung pada wanita menopause. Salah satu faktor resiko yang meningkatkan tingkat kecemasan adalah jenis kelamin. Wanita lebih sering peningkatan kecemasan secara cepat disbanding dengan pria karena respon biologik yang berbeda antara pria dan wanita dalam merespon stressor (Basof et al., 2016).

Kedua pasien pada studi kasus ini mengalami gangguan tidur akibat dari rasa takut dan cemas terhadap kondisinya. Hal ini sejalan dengan hasil penelitian sebelumnya yang mengatakan bahwa pasien gagal jantung akan mengalami gejala fisik seperti sesak napas dan gejala penyerta lainnya yang diakibatkan dari penurunan curah jantung sehingga pasien akan mengalami kesulitan dalam bernapas dan berakibat pada insomnia pada pasien (Z. M. E. Wati et al., 2020). Ansietas dapat meningkatkan kadar norepineprin dalam darah melalui stimulus sistem saraf simpatis, perubahan kimia ini menyebabkan kurangnya waktu tidur dan lebih sering terbangun (Z. M. E. Wati et al., 2020). Faktor penyebab gangguan tidur biasanya dikarenakan masalah medis kronisatau akut, atau kondisi psikologis misalnya akibat stress dan depresi (Rianjani et al., 2016)

Masalah utama pada studi kasus ini adalah ansietas dengan pengambilan masalah utama ini didasarkan pada adanya data mayor pada subjek studi kasus. Hasil ini sesuai dengan penelitian sebelumnya 
Meliawati Putri Salsabila - Penurunan kecemasan pada pasien gagal jantung kongestif melalui pemberian terapi murottal Al-Qur'an

dimana terdapat pasien gagal jantung yang mengalami kecemasan sebanyak 15 pasien (Saleh et al., 2018). Hasil ini juga sesuai pada penelitian lain yang menunjukkan pasien gagal jantung yang mengalami kecemasan dengan tingkat ringan sebanyak 4 pasien $(12,1 \%)$, sedang sebanyak 16 pasien $(48,5 \%)$, dan berat sebanyak 13 pasien $(39,4 \%)$ (Suratinoyo et al., 2016).

Intervensi studi kasus ini adalah menciptakan suasana terapeutik untuk menumbuhkan kepercayaan, gunakan pendekatan yang tenang dan meyakinkan dan menganjurkan keluarga untuk menemani pasien. Kedua pasien studi kasus ini tidak mendapatkan terapi farmakologi untuk mengurangi kecemasan, terapi farmakologi yang diterima adalah terapi untuk mengatasi masalah terkait penurunan kondisi fisik akibat gagal jantung, untuk membantu menurunkan kecemasan dan mengatasi masalah psikologi yang muncul pada pasien dilakukanlah terapi murottal al-qur'an surah Ar-Rahman yang merupakan pengembangan dari standar intervensi keperawatan Indonesia yang diterbitkan oleh PPNI. Terapi murottal al-qur'an surah Ar-Rahman sangat efektif dalam menurunkan tingkat kecemasan pada pasien dengan gagal jantung (Saleh et al., 2018). Pengukuran dan pengkajian tingkat kecemasan serta tanda-tanda vital pasien hanya dilakukan sebelum dan sesudah dilakukan terapi murottal al-qur'an surah Ar-Rahman, sedangkan setelah pemberian terapi farmakologi untuk gagal jantung yang memungkinkan memberi dampak juga terhadap perubahan tanda-tanda vital pasien tidak dilakukan pengukuran tandatanda vital ulang, hal itulah yang menjadi keterbatasan hasil pada studi kasus ini.

Hasil studi kasus ini setelah dilakukan terapi murottal al-qur'an selama 3 hari dengan masing-masing pertemuan dilakukan selama 15 menit didapatkan hasil adanya penurunan tingkat kecemasan pada pasien gagal jantung kongestif setelah diberikan terapi murottal Al-qur'an selama 3 hari. Berdasarkan studi kasus murotal alqur'an dapat me nurunkan skala kecemasan pasien gagal jantung. Hasil studi ini sesuai dengan hasil penelitian sebelumnya yang mengatakan bahwa terdapat penurunan pada tingkat kecemasan pasien pra kateterisasi jantung setelah diberikan terapi murottal al-qur'an. Tempo dan notasi pelan pada murottal al-qur'an menstimulasi pelepasan endorphin dan memberi efek relaksasi dan dapat menurunkan stress dan kecemasan (Darmadi \& Armiyati, 2019).

Penelitian lain mengatakan bahwa terapi murottal al-qur'an sangat efektif dalam menurunkan kecemasan pasien karena $\mathrm{Al}-$ qur'an memiliki stimulant yang rata-rata didominasi oleh gelombang delta yang mengindikasikan bahwa kondisi otak berada dalam keadaan rileks. Gelombang delta yang dimunculkan oleh stimulant alqur'an berada di daerah frontal dan central dimana fungsi dari daerah frontal adalah sebagai pusat intelektual umum dan control emosi serta central sebagai pusat control gerakan yang dilakukan sehngga stimulant al-qur'an dapat memberikan ketenangan, ketentraman dan kenyamanan (Lestari, 2015). Pada penelitian lain menyebutkan bahwa tingkat kecemasan pasien yang akan menjalani tindakan angiografi terjadi penurunan setelah diberikan terapi murottal al-qur'an. Terapi murottal alqur'an merupakan teknik yang sangat mudah dilakukan dan terjangkau namun memberi dampak besar pada kondisi rileks pada diri seseorang (L. Wati et al., 2020).

Terapi murottal al-qur'an efektif dalam menurunkan kecemasan dikarenakan murottal al-qur'an ini didominasi oleh gelombang delta dimana gelombang ini mengindikasi bahwa otak berada dalam keadaan yang rileks. Terapi murottal alqur'an memiliki aspek yang diperlukan dalam menurunkan kecemasan, yaitu dapat membentuk koping baru untuk mengatasi 
Meliawati Putri Salsabila - Penurunan kecemasan pada pasien gagal jantung kongestif melalui pemberian terapi murottal Al-Qur'an

kecemasan dan mendorong seseorang dalam menghadapi permasalahan (Lestari, 2015). Murottal al-qur'an memiliki lantunan yang indah sehingga memberikan dampak tubuh menjadi rileks, menurunkan hormone stress, mengalihkan perhatian pasien dari rasa cemas, tegang dan takut, mendekatkan diri kepada tuhan, serta dapat memperbaiki system kimia tubuh sehingga menurunkan tekanan darah, memperlambat pernapasan, detak jantung, denyut nadi dan aktivitas gelombang otak (Saleh et al., 2018). Pada studi kasus ini memunculkan hasil yang sama yaitu penurunan tekanan darah, nadi dan juga pernapasan kedua pasien. Penurunan tekanan darah dan denyut jantung pasien setelah diberikan terapi murottal al-qur'an ini disebabkan oleh tempo dari murottal yang lambat seiring dengan detak jantung manusia sehingga jantung akan mensinkronkan detaknya sesuai dengan tempo suara (Nafiah, 2015).

Terapi murottal al-qur'an dapat menurunkan kecemasan memberikan efek positif pada psikologis, hal ini karena ketika murottal al-qur'an diperdengarkan dan sampai ke otak yang kemudian diterjemahkan oleh otak, dalam keadaan ini otak berada pada gelombang 7-14 Hz yang merupakan keadaan energy otak yang optimal. Dalam keadaan otak yang tenang seseorang dapat berfikir jernih dan dapat membentuk koping atau harapan yang positif akan dirinya. Terapi murrotal alqur'an akan membuat kesadaran seseorang terhadap tuhan meningkat, dalam hal ini kesadaran akan kepasrahan seseorang terhadap kuasa Allah SWT (Hajiri et al., 2019). Pada hasil studi kasus ini menunjukkan bahwa pasien mengungkapkan perasaaan ikhlas terhadap kondisinya. Kebutuhan spiritual pasien gagal jantung dianggap penting. Hal ini sejalan dengan penelitian sebelumnya dengan hasil bahwa sebagian besar responden yang merupakan pasien gagal jantung sebanyak $62,7 \%$ menganggap bahwa kebutuhan spiritual merupakan kebutuhan yang penting. Perkembangan filosofis agama yang lebih matang dapat membantu seseorang untuk menghadapi kenyataan (Aidi Abshar Saman, 2017).

Kedua pasien sangat kooperatif walau dalam menjawab pertanyaan hanya secara singkat. Pasien mendengarkan dengan tenang selama murottal al-qur'an diputarkan dan menunjukkan ekspresi tenang dan rileks, pada pasien 2 bahkan sempat menangis selama proses terapi dilakukan. Setelah intervensi pada hari pertama dilakukan, kedua pasien menunjukkan keterbukaan saat pengkajian kecemasan serta pelaksanaan terapi murottal di hari kedua. Dukungan emosi yang melibatkan ekspresi, rasa empati dan perhatian dari keluarga akan membuat pasien merasa lebih baik, memperoleh keyakinannya, merasa dimiliki dan dicintai (Nurhidayati \& Rahayu, 2017). Dukungan inforkeluarga yang diberikan dapat menumbuhkan motivasi untuk melakukan pengobatan dan menenangkan hati pasien dalam menjalani pengobatan, dengan adanya dukungan ini maka memberikan peranan penting dalam keberhasilan pengobatan (Ika \& Hidayati, 2019). Hal inilah yang membuat dukungan keluarga menjadi faktor pendukung dari studi ini sehingga pasien dapat mengikuti prosedur intervensi secara kooperatif dan mendapatkan efek yang maksimal, sedangkan faktor penghambat pada studi kasus ini terdapat pada tempat pelaksaan intervensi yang kurang tenang sehingga mengganggu konsentrasi pasien selama pelaksaan intervensi.

\section{SIMPULAN}

Pasien gagal jantung kecemasan pada studi kasus ini mengungkapkan ketidakberdayaan dan kekhawatiran terhadap penyakitnya, mengalami peningkatan hemodinamika serta gangguan tidur. Dari hasil pengkajian yang dilakukan 
Meliawati Putri Salsabila - Penurunan kecemasan pada pasien gagal jantung kongestif melalui pemberian terapi murottal Al-Qur'an

pada studi kasus ini didapatkan bahwa kedua pasien mengalami masalah kecemasan. Setelah dilakukan terapi murottal al-qur'an selama 3 hari dengan durasi yang sama pada pasien 1 dan pasien 2 menunjukkan hasil bahwa terapi murottal al-qur'an surah Ar-Rahman efektif dalam menurunkan tingkat kecemasan pada pasien dengan gagal jantung kongestif. Terapi murotal al-qur'an ini merupakan salah satu tindakan non farmakologis yang dapat menstimulasi perasaan tenang dan nyaman sehingga dapat menurunkan stress dan kecemasan pasien jantung akibat keadaan dan kelemahan tubuh yang dirasakan.

Rekomendasi bagi peneliti selanjutnya selama pelaksanaan terapi murottal alqur'an surah Ar-Rahman menggunakan headset untuk mengoptimalkan tindakan yang diberikan dan meningkatkan kenyamanan pada subjek studi kasus, selain itu dilakukan juga pengukuranan kecemasan dan status hemodinamika pasien setelah pasien mendapat terapi farmakologi baik itu untuk masalah fisik maupun psikologis (bila ada) pada pasien gagal jantung. Diharapkan perawat mampu menerapkan terapi murottal al-qur'an surah Ar-Rahman ini sebagai terapi penunjang di klinik untuk menurunkan kecemasan pada pasien dengan gagal jantung.

\section{UCAPAN TERIMAKASIH}

Penulis mengucapkan terimakasih dan rasa syukur kepada Allah SWT atas segala limpahan rahmat sehingga studi kasus ini dapat terlaksana dengan baik, terimakasih kepada kedua pasien yang telah bersedia menjadi subjek pada studi kasus ini. Terimakasih kepada ibu faiz selaku kepala ruang sekaligus pembimbing klinik yang telah memberikan arahan selama pelaksanaan studi kasus.

\section{UCAPAN TERIMAKASIH}

Penulis mengucapkan terimakasih kepada keempat penderita Diabetes Melitus tipe 2 yang sudah bersedia menjadi subyek studi kasus. Terimakasih kepada dosen pembimbing yang sudah memberikan bimbingan dan arahannya, sertakepadakedua orang tua yang telahmemberikandukungan dan doa dalam menyelesaikan karya ilmiah akhir ners ini.

\section{REFERENSI}

Aidi Abshar Saman, H. K. (2017). gambaran kebutuhan spiritual pasien gagal jantung di Instalasi Elang RSUP Kariadi Semarang. 1-13.

Akhmad, A. N. (2018). Kualitas hidup pasien Gagal Jantung Kongestif (GJK) Berdasarkan karakteristik Demografi. Jurnal Keperawatan Soedirman, 11(1), 27. https://doi.org/10.20884/1.jks.2016.11.1.629

Basof, D. A., Wilson, \& M. Asroruddin. (2016). hubungan jenis kelamin, pekerjaan dan status pernikahan dengan tingkat kecemasan pada pasien operasi katarak di Rumah Sakit Yarsi pontianak.

Brunner, \& Suddart. (2014). Keperawatan medikal bedah edisi 12 .

Darmadi, S., \& Armiyati, Y. (2019). Murottal and Clasical Music Therapy Reducing Pra Cardiac Chateterization Anxiety. South East Asia Nursing Research, 1(2), 52. https://doi.org/10.26714/seanr.1.2.2019.5260

Davey, P. (2014). Medicine at a glance edisi ke 4. John Wiley \& Sons.

Donsu, R. A., Rampengan, S. H., \& Polii, N. (2020). Karakteristik Pasien Gagal Jantung Akut di RSUP Prof Dr. R. D. Kandou Periode JanuariDesember 2018. Medical Scope Journal, 1(2), 30-37. https://doi.org/10.35790/msj.1.2.2020.2746 3

Godman, H., Firouzi, A., Banya, W., Lau-walker, M., \& cowie, M. (2013). ilness perception, self-care behaviour and quality of life of heart failure patients: a longitudinal quetionnaire survey. International Journal of Nursing Studies, 945953.

Hajiri, F., Pujiastuti, S. E., \& Siswanto, J. (2019). Terapi Murottal dengan Akupresur terhadap 
Meliawati Putri Salsabila - Penurunan kecemasan pada pasien gagal jantung kongestif melalui pemberian terapi murottal Al-Qur'an

Tingkat Kecemasan dan Kadar Gula Darah pada Pasien dengan Penyakit Jantung Koroner. Jurnal Keperawatan Silampari, 2(2), 146-159. https://doi.org/10.31539/jks.v2i2.507

Ika, T., \& Hidayati, E. (2019). Family Support on Severe Frequency in Epilepsy Patients in RSUP. Dr. Kariadi Semarang. Media Keperawatan Indonesia, 2(1), 21. https://doi.org/10.26714/mki.2.1.2019.21-28

Ketut, I. ., Herdy, M., Anita, E., \& Neni, E. (2014). prevelensi tingkat kecemasan pada pasien infark miokard lama di poliklinik jantung RSUP. Prof. Dr. R.D. Kadou. Jurnal E-Clinik (ECI), 2, 1-6.

Ladwig, K., Lederbogen, F., ALbus, C., Angermann, C., Borggrefe, M., Fischer, D., Haass, F. K., Jordan, M., Kindermann, J. junger J., V, i K., Scherer, K. B., Syfarth, M., Voller, M., \& C, H. W. \& H. L. C. (2014). Position Paper on the importance of psychosocial factors in cardiology. 12 (german medical science).

Lestari, D. (2015). pengaruh terapi murottal terhadp tingkat kecemasan pasien dengan penyakit jantung koroner di ruang iccu RSUD. Dr. Soedarso Pontianak. Jurnal UNTAN.

M.F. Douglas L. (2010). Heart Failure A Companion to Braunwald's Heart Disease. Elsevier Saunders.

Nafiah, rizka zakiyyatun. (2015). Pengaruh pemberian murottal Al-Quran terhadap tekanan darah dan frekuensi denyut jantung pasien pasca operasi dengan anestesi umum di RSUD dr Moewardi Surakarta. Universitas Muhammadiyah Surakarta.

Nurhidayati, T., \& Rahayu, D. A. (2017). Dukungan Pasangan Pada Pasien Ca Payudara Yang Menjalani. Pengabdian Masyarakat, 2(9), 400404.

Paul M. Muchinsky. (2018). Analisa Praktik Klinik Asuhan Keperawatan pada Pasien Chf dengan Intervensi Inovasi Deep Breathing Exercise dan Mobilisasi Progresif Level 1 terhadap Perubahan Hemodinanik di Ruang Icu RSUD A.W.Sjahranie. Psychology Applied to Work: An Introduction to Industrial and Organizational Psychology, Tenth Edition Paul, 53(9), 16891699.

https://doi.org/10.1017/СB0978110741532 4.004

Polikandrioti, M., John, K. G., Lampros, Michalis, J.,
Koutelokos, Helen, K., Dimitrios, Moses, T. \&, \& Elisaf. (2015). Factors Associated with Depression and Anxiety of Hospitalized Patient with Heart Failure. 56, 26-35.

PPNI. (2017a). Standar Diagnosa Keperawatan Indonesia. Dewan Pengurus Pusat Persatuan Perawat Nasional Indonesia.

PPNI. (2017b). standar intervensi keperawatan indonesia edisi 1 cetakan II. Dewan Pengurus Pusat Persatuan Perawat Nasional Indonesia.

PPNI. (2017c). Standar luaran keperawatan indonesia edisi 1 cetakan II. Dewan Pengurus Pusat Persatuan Perawat Nasional Indonesia.

Pusat Jantung Nasional. (2016). Pusat Jantung Nasional Laporan Tahun 2016.

Rianjani, E., Nugroho, H. A., \& Astuti, R. (2016). Kejadian Insomnia Berdasar Karakteristik Dan Tingkat Kecemasan Pada Lansia Di Panti Wredha Pucang Gading Semarang. Jurnal Keperawatan, 4(2), 194-209.

Riskesdas. (2018). Riset Kesehatan Dasar.

Saleh, M. C. I., Agustina, D. M., Hakim, L., Afandi, M., Chamalah, E., \& Wardani, O. P. (2018). Pengaruh murottal Al-Qur'an terhadap tingkat kecemasan pada pasien jantung. Perpustakaan Nasional Katalog Dalam Terbitan (KDT), 001(2), 148. https://doi.org/10.1007/s00423006-0143-4

Smeltzer, S. C., \& B.G. Bare. (2015). Buku ajar keperawatan medikal bedah. EGC.

Suratinoyo, I., Rottle, julia V., \& Massi, G. N. (2016). Hubungan tingkat kecemasan dengan mekanisme koping pada pasien gagal jantung kongestif di ruang CVBC (Cardio Vasculer Brain Center) Lantai III RSUP. Prof. DR. R. D. Kandou Manado.

Wati, L., Mawarti, I., \& Jambi, U. (2020). Pengaruh Terapi Murottal Al-Qur'an Terhadap Tingkat Kecemasan Pasien Pre Angiografi Koroner. 1, $35-45$.

Wati, Z. M. E., Oktarina, Y., \& Rudini, D. (2020). Hubungan Tingkat Kecemasan Dengan Kualitas Tidur Pada Pasien Gagal Jantung Kongestif (Chf). 1(1), 46-57.

WHO. (2016). Prevention of cardiovascular Disease, WHO Epidemiologi Subregion AFRD and AFRE. 